\title{
Career anchors, organisational commitment and employee turnover intention in the retail sector
}

\author{
by Melinde Coetzee, AMG (Dries) Schreuder \\ and Michelle Clinton-Baker
}

\begin{abstract}
The study explored the link between the career anchors, organisational commitment and turnover intention of a sample of individuals employed in the South African retail sector. A non-probability purposive sample $(N=343)$ of employees from an organisation in the South African retail sector was utilised. The participants were represented by predominantly women (72\%) and black people (94\%) between the ages of 25 and 45 years (80\%). Following a crosssectional quantitative research approach, correlational and stepwise regression analysis was performed to achieve the objective of the study. The results showed that the entrepreneurial creativity-anchored individuals were likely to have low organisational commitment and high turnover intention, while the lifestyleanchored individuals had high levels of organisational commitment and high turnover intention. The dominant affective/normative commitment profile of the sample of participants significantly predicted low turnover intention. The findings of the study and practical implications provide useful information to managers interested in retaining staff in the retail sector.
\end{abstract}

Key words: career anchors, organisational commitment, turnover intention, lifestyle career anchor, entrepreneurial creativity career anchor, affective/ normative commitment profile

\section{Introduction}

Effectively attracting, developing, managing, motivating and retaining committed employees have become critical success factors for sustained organisational performance (Beechler \& Woodward 2009; Chang 2010; Spagnoli \& Caetano 2012). Staff shortages and an insufficient labour pool are the most common labour-related barriers to company productivity and performance (Mulaudzi 2015). Globally, the wholesale and retail sector faces high labour turnover rates which appear to be exacerbated by trends of low employee morale and motivation (Hart, Stachow, Farrell \& Reed 2007; Mulaudzi 2015). The physical and environmental conditions associated with the industry such as long hours and poor work-life balance appear to further exacerbate employee turnover in the retail sector (Hart et al 2007; Jain 2010; Mulaudzi 2015).

\footnotetext{
The authors are all members of the Department of Industrial \& Organisational Psychology at the
} University of South Africa. 
Employee turnover intention and turnover have long been topics of interest to researchers and practitioners, mainly because of the negative consequences of and high costs associated with actual turnover (Clinton-Baker 2013; Hom, Mitchell, Lee \& Griffeth 2012; Jiang, Liu, McKay, Lee \& Mitchell 2012; Siong, Mellor, Moore \& Firth 2006; Tian-Foreman 2009). Apart from negatively impacting organisational effectiveness (Pienaar, Sieberhagen \& Mostert 2007), the personal and organisational costs of voluntary employee turnover are high (Jones, Massey Kantak, Futrell \& Johnston 1996; Mallol, Holtom \& Lee 2007; Mitchell, Holtom, Lee, Sablynski \& Erez 2001). High costs for an organisation due to turnover start prior to separation as a result of lower productivity of an employee intending to leave, and continuing difficulties after actual separation (Hsu, Jiang, Klein \& Tang 2003). The costs of turnover may include both direct costs such as the costs associated with reselection and retraining and indirect costs, including the loss of valuable knowledge, skills and experience, as well as reduced morale among the remaining employees, all of which have negative consequences for labour relations (Chalkiti \& Sigala 2010; Davidson, Timo \& Wang 2010; Holtom, Mitchell, Lee \& Eberly 2008; Mitchell et al 2001). The organisation may even experience the loss of competitive position as its competitors gain insight by hiring its former employees (Hsu et al 2003). The costs resulting from turnover become even more serious when the organisation loses talented and highly committed employees (Chang 1999; Clinton-Baker 2013). These consequences of employee turnover behaviour have increased the importance of understanding the psychological factors influencing employees' turnover intention (Clinton-Baker 2013).

\section{Research objective}

In the present study, we were interested in examining voluntary turnover behaviour and more specifically psychological factors (career anchors and organisational commitment) that potentially influence the turnover intention of employees in the retail sector. The aim was therefore to assess the link between employees' career anchors, organisational commitment and turnover intention as manifested in the South African retail industry. The following two research questions were formulated:

- Do employees' career anchors significantly and positively predict their organisational commitment?

- Do employees' career anchors and organisational commitment significantly and positively predict their turnover intention?

Voluntary turnover is a function of perceived ease of movement and perceived desirability of movement (Carbery, Garavan, O'Brien \& McDonnell 2003) while turnover intention relates to the behavioural intention of individuals to leave the organisation (Bigliardi, Petroni \& Dormio 2005; Mobley, Griffeth, Hand \& Meglino 1979). Researchers have found intention to be an accurate predictor of actual turnover (McKay, Avery, Tonidandel, Morris, Hernandez \& Hebl 2007; Zimmerman \& Darnold 2009). By understanding the predictors of turnover intention, organisations can proactively introduce talent management strategies to influence employees' decision to leave and as such prevent actual turnover behaviour (Clinton-Baker 2013; Lazar 2005; Martin \& Roodt 2008). Research by Deloitte (2012) indicated talent management globally and in emerging markets as a key business strategy in retaining staff and reducing turnover intention at all levels of the organisation. 


\section{The relationship between career anchors, organisational commitment and turnover intention}

The voluntary turnover model of Steers and Mowday (1981) identified variables such as individual expectations, job experiences, affective responses to jobs, non-work-related influences, intention to stay, search for alternatives and availability of alternatives as significant antecedents of turnover behaviour. Ding and Lin (2006) indicated that workrelated attitudes such as career and job satisfaction and organisational commitment have significant effects on turnover intention. Research by Chang (2010) provided evidence of a significant association between employees' career anchors and their turnover behaviour. He proposed that by understanding employees' career anchors and satisfying the underlying needs and intrinsic motivations that underpin individuals' career anchors, strategies can be developed to reduce turnover. Hsu et al (2003) indicated that employees whose internal career anchors are compatible with their jobs record lower intentions to leave their organisations. Based on their findings, they also suggest that organisations should introduce appropriate talent management strategies in order to reduce turnover based on their employees' different career motivations. Creating satisfactory career paths and challenging job opportunities is indicated as a top priority in contemporary talent management approaches (Deloitte 2012). Sudha (2012) also found employee career development to be a key factor in retaining staff in the retail sector.

Research indicates that individuals' career motives and values (career anchors) have an impact on career decision making and psychological attachment or commitment to an occupation or organisation (Feldman \& Bolino 2000; Kniveton 2004; Schein 1996). According to Schein (1996), a career anchor is an individual's occupational selfconcept, comprising self-perceived talents and abilities, basic values and motives and needs. These talents, values and motives, in turn, influence an individual's career decisions. If organisations understand the relationship between career anchors (what drives employees' career decisions), organisational commitment, that is, the psychological mindsets that bind the individual to the organisation (Allen \& Meyer 1990), and whether employees intend leaving an organisation (turnover intention), they will be able to proactively introduce talent management strategies to increase organisational commitment levels and reduce turnover intention (Clinton-Baker 2013). Research by Deloitte (2012) indicated that sustaining employee morale, engagement and commitment is a key priority in contemporary talent management.

\subsection{Career anchors}

A career anchor reflects individuals' career-related self-concepts, which constitute a combination of self-perceived values, abilities, interests, motives and needs relating to professional work choices (Barclay, Chapman \& Brown 2013; Schein 1996). Career anchors, once moulded by work and life experiences, are relatively stable and as such give stability and direction to a person's career (Schein 1996; 2013). The concept of career anchors helps individuals and organisations understand the value of personenvironment fit or congruence in career success and satisfaction (Barclay et al 2013). Career anchor theory (Schein 1971; 1978) assumes that individuals would be most satisfied and productive when the individual perceives optimal congruence between the career anchor and the job and work environment (Leong, Rosenberg \& Chong 2014).

Schein $(1971 ; 1978 ; 1996 ; 2013)$ differentiates between eight career anchors, each with a unique set of underpinning motivations and needs: (1) technical/functional 
competence (motivated by advancement and opportunities for self-development only in one's technical or functional area of competence); (2) general managerial competence (motivated by opportunities to analyse and solve problems and harness people together to achieve common goals); (3) autonomy/independence (motivated to seek work situations that are free of organisational constraints; setting own schedule and pace of work; excited by sense of freedom); (4) security/stability (motivated by stable, predictable work, job security and long-term attachment to one organisation); (5) entrepreneurial creativity (motivated by the need to build or create something that is entirely one's own project, likes to move from project to project, interested in initiating new enterprises, motivated by constant new challenges to conquer and create new products or services); (6) service/dedication to a cause (motivated to improve the world in some fashion; wants to align work activities with personal values related to improving society); (7) pure challenge (motivated to overcome major obstacles, solve unsolvable problems, or win out over extremely tough opponents; single-minded pursuit of selftests); and (8) lifestyle (motivated to balance career with lifestyle needs; highly concerned with issues such as paternity/maternity leave, daycare options and workhome flexibility).

Career anchors influence every major decision about career issues, including individuals' subjective experiences of career success, decisions to move, employee reactions to work experiences and their choice of career and workplace (Clinton-Baker 2013; Herrbach \& Mignonac 2012; Mignonac \& Herrbach 2003). A number of research findings support the premise that employees who experience a match between their career anchors and their job setting report higher job satisfaction, more commitment to their organisation and lower intentions to leave than those employees who experience a mismatch (Lumley, Coetzee, Tladinyane \& Ferreira, 2011; Steele \& Francis-Smythe 2010; Coetzee, Schreuder \& Tladinyane 2007, 2014; Quesenberry \& Trauth 2012).

\subsection{Organisational commitment}

Employees' commitment to an organisation comprises multiple mindsets of commitment (Meyer, Morin \& Vandenberghe 2015). In the present study, organisational commitment is understood in the context of Allen and Meyer's (1990) three-component model of organisational commitment, which distinguishes between three distinct mindsets: (1) emotional attachment (affective commitment), (2) sense of obligation (normative commitment), and (3) perceived cost of leaving (continuance commitment). Kuo (2013) views employees' organisational commitment as an effective and highly influential mechanism for connecting employees and the organisation. Research provides evidence of positive associations between employees' organisational commitment and a variety of desirable work outcomes such as employee job satisfaction, motivation and performance, and negative associations between commitment and absenteeism and turnover (Ezirim, Nwibere \& Emecheta 2012; Lumley et al 2011; Saif, Nawaz, Jan \& Khan 2012).

Numerous meta-analyses have substantiated the premise that the higher the commitment levels of the employee, the lower the predicted turnover intention will be (Bentein, Vandenberg, Vandenberghe \& Stinglhamber 2005; Joo \& Park 2010; Lazar 2005; Lee \& Liu 2007; Martin \& Roodt 2008; Meyer, Hecht, Gill \& Toplonytsky 2010; Yin-Fah, Foon, Chee-Long \& Osman 2010). Research has also established that a dominant affective commitment/normative commitment profile is a significantly stronger predictor of turnover intention and actual turnover than continuance commitment (Lazar 2005; Somers 1995). 
Employees' organisational commitment has also been associated with their internal motivation (feeling of accomplishment and self-fulfilment) which, in turn, shows a strong direct negative relationship with turnover intention (Dysvik \& Kuvaas 2010; Mathieu \& Zajac 1990). Researchers also indicate that organisations wishing to increase the commitment of their employees should strive for congruence between organisational rewards and the motivations and values underlying their employees' career anchors (Coetzee et al 2007; Hsu et al 2003; Kniveton 2004). From an organisation's perspective, research on career anchors can be used to guide current selection, placement, development and reward practices. In addition, an organisation might be able to improve employees' retention (or reduce turnover) by matching career opportunities to employees' career anchors (Ramakrishna \& Potosky 2003). Commitment strategies may further be used to forge psychological bonds between the organisation's and employee's goals and thereby reduce turnover intention (ClintonBaker 2013; Döckel 2003).

\section{Research method}

A cross-sectional survey design using primary data was used to fulfil the research objectives.

\subsection{Participants}

A non-probability purposive sample $(\mathrm{N}=343)$ of employees from an organisation in the South African retail sector was used. The sample was predominantly made up of women $(72 \%)$ and black people $(94 \%)$ who were employed at general staff level $(73 \%)$. The participants were predominantly in the establishment stage of their life-career (ages 25-45 years: $80 \%$ ).

\subsection{Measuring instruments}

Career anchors: The career orientations inventory (COI) developed by Schein (2006) was used to measure the participants' career anchors. The COI (Schein 2006) is a selfreport measure comprising 40 items. Responses are captured on a six-point Likert-type scale. The COI measures eight career preferences: technical/functional competence (5 items), general managerial competence (5 items), entrepreneurial creativity (5 items), security/stability (5 items), autonomy/independence ( 5 items), lifestyle (5 items), service/dedication to a cause (5 items) and pure challenge (5 items). The col has evidenced satisfactory psychometric validity and reliability in other South African multicultural samples (Coetzee \& Schreuder 2008, 2009; Coetzee et al 2007). In the present study, the following internal consistency reliability coefficients were obtained: technical/functional competence (.47), general managerial competence (.55), entrepreneurial creativity (.65), security/stability (.61), autonomy/independence (.73), lifestyle (.64), service/dedication to a cause (.45) and pure challenge (.61). Although the desired cut-off for internal consistency reliability is .70, Hair, Black, Babin and Anderson (2010) deem the lower limit of acceptability to be .60 for broad research purposes. For the purpose of this research, therefore, only the career anchor variables with Cronbach's alpha coefficients above .60 were considered in the statistical analysis (entrepreneurial creativity, security/stability, autonomy/independence, lifestyle and pure challenge).

Organisational commitment: The organisational commitment questionnaire (OCQ) developed by Meyer and Allen (1997) was used to measure the participants' three commitment mindsets on a seven-point Likert-type scale: affective commitment 
(6 items), continuance commitment (6 items) and normative commitment (6 items). The OCQ reported acceptable internal consistency reliability coefficients ranging between .74 and .87 (Briscoe \& Finkelstein 2009; Meyer, Allen \& Smith 1993). Allen and Meyer (1996) also attest to the questionnaire's having convergent and discriminative validity. Studies by Coetzee et al (2007) and Lumley et al (2011) have confirmed the reliability and validity of the OCQ in the South African context. In terms of the present study, the following internal consistency reliability coefficients were obtained: affective commitment (.65); continuance commitment (.61) and normative commitment (.68). The overall scale registered a Cronbach alpha value of .73. The alpha coefficients were regarded as acceptable for the purposes of the research, as indicated by the guideline provided by Hair et al (2010).

Turnover intention: The turnover intention scale (TIS) developed by Mobley et al (1979) was used to measure the participants' turnover intention by means of three items: desire to quit ("I think a lot about leaving this organisation"), seriously thinking about quitting ("I am actively searching for an acceptable alternative to this organisation"), and intention to quit ("When I can, I will leave the organisation"). Responses were captured on a seven-point Likert-type scale. Joo and Park (2010) and Yin-Fah et al (2010) found that the alpha coefficient for the three items was .82 and .90 respectively. In terms of the present study, the scale showed acceptable internal consistency reliability with a Cronbach alpha value of .77 .

\subsection{Research procedure}

Ethical clearance to conduct the study was obtained from the research institution and permission for employees to participate in the research study was obtained from the CEO of the retail company. Participation was voluntary and employees were afforded the opportunity to attend allocated sessions. At the beginning of each session, the researcher explained the purpose of the research and the participants were assured of confidentiality and anonymity and the voluntary nature of participation. A covering letter was provided explaining the purpose of the research, procedure, potential benefits, confidentiality, anonymity, participation and withdrawal. All the participants were also asked to complete a written consent form. They completed the questionnaires in a session allocated for this purpose and returned the completed questionnaires to the researcher who coordinated the session.

\subsection{Statistical analysis}

The Statistical Package for the Social Sciences (SPSS 2010) was used to analyse the data for the quantitative analysis. Descriptive statistics and correlational and stepwise multiple regression analyses were conducted. Pearson Product-Moment correlations were calculated to assess the direction and strength of the relationships between the variables. In order to counter the probability of a type I error, the significance value was set at the 95\% confidence interval level $(p \leq 0.05)$. The practical significance of the correlations was interpreted by using Cohen's (1992) guidelines: $r \leq .10$ (small practical effect); $r \leq .30$ (moderate practical effect); and $r \geq .50$ (large practical effect). Multicollinearity concerns were set at $r \geq .90$ (Hair et al 2010).

Three stepwise regression models were performed. In the first model, the career anchor variables were entered as independent variables and the overall organisational commitment variable was regarded as the dependent variable. The second model treated the career anchor variables as independent variables and the overall turnover intention variable as the dependent variable. The three organisational commitment 
variables were treated as independent variables in the third regression model, and turnover intention as the dependent variable. The stepwise regression procedure defines an a posteriori order based on the relative uniqueness of the variables in the sample at hand. The procedure is designed to select from the group of independent variables in each model the one variable at each stage which has the largest $s r^{2}$, and hence makes the largest contribution to $R^{2}$. The program stops admitting independent variables into the equation when no independent variable makes a contribution at $p \leq$ 0.05 (Tabachnick \& Fidell 2007). Using Cohen's (1992) guidelines, $R^{2}$ values $(p \leq 0.05)$ of $\leq 0.12$ (small practical effect) and $\geq 0.13 \leq 025$ (medium practical effect) were also considered in the interpretation of the results.

\section{Results}

\subsection{Descriptive statistics}

The means, standard deviations and Cronbach alpha coefficients of the variables relevant to the statistical analysis are reported in Table 1. The participants obtained the highest mean scores on the lifestyle career anchor (Mean $=4.97$; $\mathrm{SD}=1.35$ ) and the lowest mean score on the autonomy/independence career anchor (Mean $=3.81$; $\mathrm{SD}=$ 1.32). In terms of organisational commitment, the participants obtained the highest mean score on affective commitment (Mean $=4.86 ; \mathrm{SD}=1.08)$ and the lowest score on continuance commitment (Mean $=4.59$; $\mathrm{SD}=1.52)$.

Table 1

Descriptive statistics for the total sample $(\mathrm{N}=343)$

\begin{tabular}{|l|l|l|l|l|l|l|l|l|l|l|l|l|l|}
\hline & \multicolumn{1}{|c|}{ Variables } & Mean & SD & $\mathbf{\alpha}$ & $\mathbf{1}$ & $\mathbf{2}$ & $\mathbf{3}$ & $\mathbf{4}$ & $\mathbf{5}$ & $\mathbf{6}$ & $\mathbf{7}$ & $\mathbf{8}$ & $\mathbf{9}$ \\
\hline 1 & $\begin{array}{l}\text { Autonomy/ } \\
\text { independence }\end{array}$ & 3.81 & 1.32 & .73 & & & & & & & & & \\
\hline 2 & Security/stability & 4.23 & 1.26 & .61 & & & & & & & & & \\
\hline 3 & $\begin{array}{l}\text { Entrepreneurial } \\
\text { creativity }\end{array}$ & 4.07 & 1.50 & .65 & & & & & & & & & \\
\hline 4 & Pure challenge & 4.78 & 1.17 & .61 & & & & & & & & & \\
\hline 5 & Lifestyle & 4.97 & 1.35 & .64 & & & & & & & & & \\
\hline 6 & $\begin{array}{l}\text { Affective } \\
\text { commitment }\end{array}$ & 4.86 & 1.08 & .65 & $-.19^{* * *}$ & -.03 & $-.28^{* * *}$ & .01 & $-.11^{*}$ & & & & \\
\hline 7 & $\begin{array}{l}\text { Continuance } \\
\text { commitment }\end{array}$ & 4.59 & 1.52 & .61 & .04 & $.12^{*}$ & .07 & .05 & -.03 & & & & \\
\hline 8 & $\begin{array}{l}\text { Normative } \\
\text { commitment }\end{array}$ & 4.70 & 1.11 & .68 & -.07 & -.04 & $-.20^{* * *}$ & .09 & -.10 & & & & \\
\hline 9 & $\begin{array}{l}\text { Overall } \\
\text { organisational } \\
\text { commitment }\end{array}$ & 4.72 & .89 & .73 & -.08 & .04 & $-.16^{* *}$ & .07 & -.11 & & & & \\
\hline 10 & $\begin{array}{l}\text { Turnover } \\
\text { intention }\end{array}$ & 4.10 & 1.66 & .77 & $.21^{* * *}$ & .07 & $.31^{* * *}$ & -.03 & $.21^{* * *}$ & $-.54^{* * *}$ & -.01 & $-.43^{* * *}$ & $-.40^{* * *}$ \\
\hline
\end{tabular}

${ }^{* * *} p \leq .001$ - statistically significant. ${ }^{* *} p \leq .01$ - statistically significant. ${ }^{*} p \leq .05-$ statistically significant.

The turnover intention average score for the sample was 4.10 out of 7 . A higher score represents higher intentions to leave the organisation. A frequency distribution, which is indicated in Table 2, further examines the intention of respondents to leave their organisation. Out of the sample, $30 \%$ scored a 3 or lower out of 7 on the turnover intention scale, indicating that the organisation could lose $70 \%$ of these employees. 
Table 2

Descriptive statistics: frequency distribution for turnover intention ( $n=343$ )

\begin{tabular}{|c|c|c|c|}
\hline $\begin{array}{c}\text { Turnover intention } \\
\text { values }\end{array}$ & Frequency & Percentage & $\begin{array}{l}\text { Cumulative } \\
\text { percentage }\end{array}$ \\
\hline 1.00 & 18 & 5.2 & 5.2 \\
\hline 1.33 & 8 & 2.3 & 7.6 \\
\hline 1.67 & 14 & 4.1 & 11.7 \\
\hline 2.00 & 23 & 6.7 & 18.4 \\
\hline 2.33 & 7 & 2.0 & 20.4 \\
\hline 2.67 & 14 & 4.1 & 24.5 \\
\hline 3.00 & 19 & 5.5 & 30.0 \\
\hline 3.33 & 20 & 5.8 & 35.9 \\
\hline 3.67 & 17 & 5.0 & 40.8 \\
\hline 4.00 & 23 & 6.7 & 47.5 \\
\hline 4.33 & 21 & 6.1 & 53.6 \\
\hline 4.67 & 34 & 9.9 & 63.6 \\
\hline 5.00 & 25 & 7.3 & 70.8 \\
\hline 5.33 & 25 & 7.3 & 78.1 \\
\hline 5.67 & 14 & 4.1 & 82.2 \\
\hline 6.00 & 26 & 7.6 & 89.8 \\
\hline 6.33 & 12 & 3.5 & 93.3 \\
\hline 6.67 & 9 & 2.6 & 95.9 \\
\hline 7.00 & 14 & 4.1 & 100.0 \\
\hline Total & 343 & 100.0 & \\
\hline
\end{tabular}

\subsection{Correlational statistics}

Overall, the correlations were well below the cut-off for concerns about multicollinearity: $r \geq .90$ (Hair et al 2010). Table 1 shows that affective commitment had significant negative associations with the career anchors of autonomy/independence $(r=-.19 ; p \leq$ .001 ; small practical effect), entrepreneurial creativity $(r=-.28 ; p \leq .001$; small practical effect) and lifestyle ( $r=-.11 ; p \leq .05$; small practical effect). Only the entrepreneurial creativity career anchor showed a significant negative association with normative commitment $(r=-.20 ; p \leq .001$; small practical effect) and overall organisational commitment ( $r=-.16 ; p \leq .01$; small practical effect).

The autonomy/independence $(r=.21 ; p \leq .001$; small practical effect), entrepreneurial creativity $(r=.31 ; p \leq .001$; moderate practical effect) and lifestyle $(r=.21 ; p$ $\leq .001$; small practical effect) career anchors showed significant positive associations with turnover intention. Affective commitment ( $r=-.54 ; p \leq .001$; large practical effect), normative commitment $(r=-.43 ; p \leq .001$; moderate practical effect) and overall organisational commitment $(r=-.40 ; p \leq .001$; moderate practical effect) showed significant negative associations with turnover intention. The collinearity statistics (variance inflation factor [VIF] and the tolerance score) were also computed to determine the extent of multicollinearity. The scores found for the current study were all well below 10, and multicollinearity was therefore not considered to be a concern in the interpretation of the beta values. 


\subsection{Stepwise regression analysis}

Three stepwise regression models were performed. In the first model, the career anchor variables were entered as independent variables and the overall organisational commitment variable was regarded as the dependent variable. Model 1 (Table 3) shows that the model (step 2$)$ explained $5 \%\left(R^{2}=.05 ; \mathrm{F} p \leq .001\right.$; small practical effect) of the variance in organisational commitment. Only entrepreneurial creativity $(B=-.20$; $p \leq .001)$ and lifestyle $(B=.19 ; p \leq .001)$ significantly contributed to explaining the variance in organisational commitment, with entrepreneurial creativity accounting for most of the variance and negatively.

Table 3

Stepwise regression analysis: career anchors as independent variables and organisational commitment as the dependent variable

\begin{tabular}{|c|c|c|c|c|c|c|c|c|}
\hline \multirow[t]{2}{*}{ Model 1} & \multicolumn{2}{|c|}{$\begin{array}{l}\text { Unstandardised } \\
\text { coefficients }\end{array}$} & \multirow{2}{*}{\begin{tabular}{|c|}
$\begin{array}{c}\text { Standardised } \\
\text { coefficients }\end{array}$ \\
Beta $(\boldsymbol{\beta})$ \\
\end{tabular}} & \multirow{2}{*}{$\mathbf{t}$} & \multirow{2}{*}{ Sig. } & \multirow[t]{2}{*}{$\mathbf{F}$} & \multirow{2}{*}{$\begin{array}{c}\text { Adjusted } \\
R^{2}\end{array}$} & \multirow[t]{2}{*}{$\mathbf{R}$} \\
\hline & B & Std. error & & & & & & \\
\hline (Constant) & 5.10 & 0.14 & & 37.11 & $0.00^{x * *}$ & $8.52^{\mathrm{nt}}$ & 0.02 & 0.16 \\
\hline $1 \begin{array}{l}\text { Entrepreneurial } \\
\text { creativity }\end{array}$ & -0.09 & 0.03 & -0.16 & -2.92 & $0.00^{*+*}$ & & & \\
\hline (Constant) & 4.44 & 0.23 & & 19.58 & $0.00^{x * x}$ & $10.77^{\mathrm{xx \times}}$ & 0.05 & 0.15 \\
\hline $2 \begin{array}{l}\begin{array}{l}\text { Entrepreneurial } \\
\text { creativity }\end{array} \\
\end{array}$ & -0.12 & 0.03 & -0.20 & -3.66 & $0.00^{* * * * *}$ & & & \\
\hline Lifestyle & 0.16 & 0.05 & 0.19 & 3.57 & $0.00^{\text {xix }}$ & & & \\
\hline
\end{tabular}

${ }^{* * *} p \leq .001$ - statistically significant. ${ }^{* *} p \leq .01-$ statistically significant. ${ }^{*} p \leq .05-$ statistically significant.

The second model (Table 4 ) treated the career anchor variables as independent variables and the overall turnover intention variable as the dependent variable. Similar to the pattern observed in terms of organisational commitment (model 1), Table 2 shows that the model (step 2) explained 13\% $\left(R^{2}=.13\right.$; F $p \leq .001$; moderate practical effect) of the variance in turnover intention. Only entrepreneurial creativity $(B=.31 ; p \leq$ $.001)$ and lifestyle $(B=.20 ; p \leq .001)$ significantly contributed to explaining the variance in organisational commitment, with entrepreneurial creativity accounting for most of the variance.

Table 4

Stepwise regression analysis: career anchors as independent variables and turnover intention as dependent variable

\begin{tabular}{|c|c|c|c|c|c|c|c|c|}
\hline \multirow[t]{2}{*}{ Model 2} & \multicolumn{2}{|c|}{$\begin{array}{c}\text { Unstandardised } \\
\text { coefficients }\end{array}$} & \multirow{2}{*}{$\begin{array}{c}\begin{array}{c}\text { Standardised } \\
\text { coefficients }\end{array} \\
\text { Beta }(\beta)\end{array}$} & \multirow{2}{*}{ t } & \multirow{2}{*}{ Sig. } & \multirow[t]{2}{*}{$\mathbf{F}$} & \multirow{2}{*}{$\begin{array}{c}\text { Adjusted } \\
R^{2}\end{array}$} & \multirow[t]{2}{*}{$\mathbf{R}$} \\
\hline & B & Std error & & & & & & \\
\hline (Constant) & 2.69 & 0.25 & & 10.86 & $0.00^{* * *}$ & $37.06^{\text {n*** }}$ & 0.10 & 0.31 \\
\hline $1 \begin{array}{l}\begin{array}{l}\text { Entrepreneurial } \\
\text { creativity }\end{array} \\
\text { retis }\end{array}$ & 0.35 & 0.06 & 0.31 & 6.09 & $0.00^{*+* *}$ & & & \\
\hline (Constant) & 1.48 & 0.39 & & 3.83 & $0.00^{* * * *}$ & $27.40^{\text {wat }}$ & 0.13 & 0.37 \\
\hline $2 \begin{array}{l}\text { Entrepreneurial } \\
\text { creativity }\end{array}$ & 0.34 & 0.06 & 0.31 & 6.08 & $0.00^{* * *}$ & & & \\
\hline Lifestyle & 0.25 & 0.06 & 0.20 & 4.01 & $0.00^{\mathrm{x} * *}$ & & & \\
\hline
\end{tabular}

${ }^{* * *} p \leq .001-$ statistically significant. ${ }^{* *} p \leq .01-$ statistically significant. ${ }^{*} p \leq .05-$ statistically significant.

In model 3 (Table 5), the three organisational commitment variables were treated as independent variables and turnover intention as the dependent variable. Table 5 shows 
that the model (step 2$)$ explained $32 \%\left(R^{2}=.32 ; \mathrm{F} p \leq .001\right.$; large practical effect) of the variance in turnover intention. Only affective commitment $(B=-.43 ; p \leq .001)$ and normative commitment $(B=-.21 ; p \leq .001)$ significantly and negatively contributed to explaining the variance in turnover intention, with affective commitment accounting the most for the variance.

Table 5

Stepwise regression analysis: organisational commitment as the independent variable and turnover intention as the dependent variable

\begin{tabular}{|c|c|c|c|c|c|c|c|c|}
\hline \multirow{2}{*}{ Model 3} & \multicolumn{2}{|c|}{$\begin{array}{c}\text { Unstandardised } \\
\text { coefficients }\end{array}$} & \multirow{2}{*}{$\begin{array}{c}\begin{array}{c}\text { Standardised } \\
\text { coefficients }\end{array} \\
\text { Beta }(\boldsymbol{\beta})\end{array}$} & \multirow{2}{*}{$\mathbf{t}$} & \multirow{2}{*}{ Sig. } & \multirow{2}{*}{$\mathbf{F}$} & \multirow{2}{*}{$\begin{array}{c}\text { Adjusted } \\
R^{2}\end{array}$} & \multirow{2}{*}{$\mathbf{R}$} \\
\hline & B & Std error & & & & & & \\
\hline (Constant) & 8.10 & 0.35 & & 23.11 & $0.00^{* * *}$ & 136.63 & 0.29 & 0.54 \\
\hline 1 affective & -0.82 & 0.07 & -0.53 & -11.69 & $0.00^{* * *}$ & & & \\
\hline (Constant) & 8.79 & 0.38 & & 23.02 & $0.00^{* * *}$ & 79.81 & 0.32 & 0.57 \\
\hline 2 affective & -0.66 & 0.08 & -0.43 & -8.23 & $0.00^{* * *}$ & & & \\
\hline normative & -0.32 & 0.08 & -0.21 & -4.09 & $0.00^{* * *}$ & & & \\
\hline
\end{tabular}

${ }^{* * *} p \leq .001-$ statistically significant. ${ }^{* *} p \leq .01-$ statistically significant. ${ }^{*} p \leq .05-$ statistically significant.

\section{Discussion}

The study explored the link between the career anchors, organisational commitment and turnover intention of a sample of individuals employed in the South African retail sector. Turnover intention is of high concern to managers in the retail sector (ClintonBaker 2013; Mulaudzi 2015). The results of the present study also showed that the present sample of participants had high levels of turnover intention (i.e. reduced level of commitment and high desire to leave the organisation). We expected that understanding how the participants' career anchors relate to their organisational commitment, and how these two sets of variables in turn relate to their turnover intention, might provide deeper insight into their turnover intention. Research on career anchors indicated that generally people stay engaged in a certain job or are committed to an organisation because of a sense of congruence between career anchor and work environment (Coetzee et al 2007; Wils, Wils \& Tremblay 2010). Career anchors influence every major decision about career issues, including decisions to move, employee reactions to work experiences and employees' choice of career and workplace (Herrbach \& Mignonac 2012; Mignonac \& Herrbach 2003), while organisational commitment has been shown to further explain the reasons why individuals prefer to stay within the organisation (Lumley et al 2011; Mowday, Porter \& Steers 1982). Although the career anchor profile of the present sample reflected a strong need for security/stability, followed by lifestyle, pure challenge and entrepreneurial creativity needs, only the entrepreneurial creativity and lifestyle career anchors offered an explanation for the participants' organisational commitment and turnover intention.

The significant associations between the career anchors and organisational commitment corroborate research suggesting that individuals' self-identity influences the nature of employees' commitment in the workplace (Meyer et al 2015). In terms of the present study, the entrepreneurial creativity-anchored individuals were likely to have low organisational commitment and high turnover intention. This is hardly surprising since individuals with a need to create and experience new challenges would prefer to own their own business instead of working for someone else. Wealth, 
ownership freedom and power are vital to these individuals (Coetzee \& Schreuder $2008,2009)$. Coetzee et al (2007) also found the entrepreneurially anchored individual to have significantly low organisational commitment. Their overriding motivation is a need for change, personal freedom, challenge, developing own projects and taking risks to obtain personal prominence (Barclay et al 2013; Leong et al 2014; Schein 1990).

The results in terms of the organisational commitment and turnover intention of the lifestyle-anchored participants appear to be in conflict with previous research. Overall, the sample of participants' organisational commitment profile reflected high overall commitment and an affective/normative commitment (AC/NC) dominant profile, which significantly explained the participants' overall low levels of turnover intention. The AC/NC-dominant profile reflects a sense of moral commitment, that is, a desire to do what is right (Meyer et al 2015; Meyer, Stanley \& Parfyonova 2012). The results of the overall commitment profile are in agreement with research that showed that a dominant $\mathrm{AC} / \mathrm{NC}$ profile was generally associated with low levels of turnover intention (Gellatly, Meyer \& Luchak 2006; Meyer et al 2015) and was consistently shown to be a strong indicator in examining employees' intent to leave an organisation (Allen \& Meyer 1996; Lazar 2005), and in retaining employees (Manetje \& Martins 2009). However, contrary to previous research, the results of the present study suggested that although the lifestyle-anchored participants were likely to have high levels of organisational commitment, they were also likely to have high turnover intention. Coetzee et al (2007) also found in this regard that low lifestyle needs were associated with low organisational commitment.

The high turnover intention of the lifestyle-anchored participants could possibly be attributed to the need for flexibility and the desire to balance and integrate work-lifecareer needs. Research has also indicated that poor work-life balance contributed to employee turnover in the retail sector (Hart et al 2007; Jain 2010; Mulaudzi 2015). The findings of our study suggest that the career anchored-need for flexibility and work-life balance may override the sense of moral obligation towards the organisation. If the career-related needs of lifestyle-anchored individuals cannot be achieved within the organisation, they are less likely to remain with the organisation, indicating that their commitment to their family and personal life might be higher than their commitment to the organisation (Clinton-Baker 2013). Schein (2013) noted from his previous research that individuals with a lifestyle orientation were often impatient with the restrictions of their organisational careers and were looking for ways to break out in order to achieve greater work-life integration. Working in the retail environment involves long hours, including weekends (Clinton-Baker 2013). Individuals who prioritise the need to integrate individual, family and career commitments and who look for company benefits that allow flexible working arrangements may find that their values and needs do not align with the values and needs of the organisation (Coetzee \& Schreuder 2008, 2009) and they are therefore more likely to have higher turnover intentions.

\section{Conclusions, implications, limitations and recommendations}

\subsection{Conclusions and implications for practice}

Managers concerned about positive employee relations and retaining employees should take note of the findings of the present study in their approach to talent management. Jain (2010) corroborates the importance of managers in retail organisations ensuring that programmes are in place to identify, attract and prevent the 
loss of high potential talent in the industry as a result of the high turnover rates. Overall, the findings indicated that $70 \%$ of the participants have high turnover intentions. With $70 \%$ of the sample scoring over 3.00 , commitment strategies need to be implemented to reduce the potential number of employees voluntarily leaving the organisation. In this regard, the participants' career anchors and organisational commitment offered a meaningful explanation of their turnover intention. Employees' organisational commitment is seen as an effective and highly influential mechanism for connecting employees and the organisation (Kuo 2013) and for achieving lower levels of absenteeism and turnover (Saif et al 2012). The current study highlighted the entrepreneurial creativity and lifestyle career anchors and the dominant AC/NC profile as important predictors of the participants' turnover intention. In line with previous research, the findings further showed that the unique motivations underlying the career-related needs of these two career anchors significantly helped to explain their commitment and turnover intention. Research by Deloitte (2012) indicated organisational support, including customised or individualised career planning and job advancement guidelines and expectations, as an important talent management strategy. Sudha (2012) indicated personal discussions with employees in the retail sector regarding career development opportunities within the organisation as important in retaining employees.

Managers should note that as the world becomes more dynamic and complex, and career mobility opportunities increase for employees, the opportunities for individuals with the entrepreneurial creativity anchor to create their own businesses across the globe will increase dramatically. This group of individuals could become a major source of new jobs for the other career anchor groups (Schein 2013), which could potentially influence their commitment and turnover intention. Managers in the retail sector should therefore consider creating a work environment that encourages and rewards entrepreneurship in order to maintain positive relations with entrepreneurially anchored employees with a view to building their commitment to the organisation and retaining them. This group of employees can be a major source of creativity and innovation for the organisation (Schein 2013).

Managers in the retail sector should also take cognisance of the increased importance of the shifting lifestyle needs of their employees. The physical and environmental conditions associated with the industry, such as long hours and poor work-life balance, have been indicated as factors contributing to employee turnover in the retail sector (Hart et al 2007; Jain 2010; Mulaudzi 2015). Meister and Willyerd (2010) predict that as the workplace evolves in terms of increased globalisation, virtual employment and mobile technology, individual's concerns about work-life flexibility and integration will increase as they attempt to manage both their working lives and their personal lives better. The findings of the present study showed that although lifestyleanchored employees may be highly committed to the organisation, they may also have high turnover intentions. Managers should consider the lifestyle-anchored employee's needs for work-home flexibility and an organisational climate that respects personal and family concerns and that makes renegotiation of the psychological contract possible in order to maintain positive relations with the employee. Typical rewards that the lifestyle-anchored employee values include options for travelling or moving when family issues permit, part-time work if life concerns require this, sabbaticals, paternity and maternity leave, day-care options, and flexible work arrangements (Coetzee et al 2007). 


\subsection{Methodological limitations and recommendations}

Although our study contributed meaningful insights on the psychological factors (career anchor motivations/needs and organisational commitment mindsets) that influence employees' turnover intention, there are a number of limitations that need to be addressed in future research. The study used a cross-sectional design with a single sample in a retail organisation which limited the generalisability of the results. The cross-sectional nature of the research design further does not allow for cause-effect interpretation of the associations between the variables. Future research should endeavour to include a larger sample with broader representation of various occupational and socio-demographic groups in order to have a broader representation of the career anchors. More research is required to assess the joint role of career anchors and organisational commitment in predicting employees' turnover intention. The cross-sectional (single-source) nature of the research design and data has the potential for common method variance which should be investigated in future replication studies. Data should be obtained from multiple sources or at multiple time periods.

Despite its limitations, this study makes a valuable contribution to the literature and practice. Although researchers investigated the association between individuals' career anchors and organisational commitment (Coetzee et al 2007), and their commitment and turnover intention (Manetje \& Martins 2009) in the South African organisational context, this study is the first to assess the relationship between these three variables in a single study in the retail sector. In this regard, the findings add new insights to the career and talent management literature. The study also provided potentially useful information to managers interested in retaining staff in the retail sector.

\section{List of references}

Allen, NJ \& Meyer, JP. 1990. The measurement and antecedents of affective, continuance and normative commitment to the organization. Journal of Occupational Psychology 63:1-18.

Allen, NJ \& Meyer, JP. 1996. Affective, continuance, and normative commitment to the organization: An examination of construct validity. Journal of Vocational Behavior 49: 252-276.

Barclay, WB, Chapman, JR \& Brown, BL. 2013. Underlying factor structure of Schein's career anchor model. Journal of Career Assessment 21(3):430-451.

Beechler, S \& Woodward, IC. 2009. The global "war for talent". Journal of International Management 15:273-285.

Bentein, K, Vandenberg, R, Vandenberghe, C \& Stinglhamber, F. 2005. The role of change in the relationship between commitment and turnover: A latent growth modelling approach. Journal of Applied Psychology 90(3):468-482.

Bigliardi, B, Petroni, A, \& Dormio Al. 2005. Organizational socialization, career aspirations and turnover intentions among design engineers. Leadership and Organization Development Journal 26(6):424-41.

Briscoe, JP \& Finkelstein, LM. 2009. The "new career" and organizational commitment: Do boundaryless and protean attitudes make a difference? Career Development International 14(3):242-260. 
Carbery, R, Garavan, TN, O’Brien, F, \& McDonnell, J. 2003. Predicting hotel managers' turnover cognitions. Journal of Managerial Psychology 18(7):649-679.

Chalkiti, K \& Sigala, M. 2010. Staff turnover in the Greek tourism industry: A comparison between insular and peninsular regions. International Journal of Contemporary Hospitality Management 22(3):335-359.

Chang, E. 1999. Career commitment as a complex moderator of organizational commitment and turnover intention. Human Relations 52(10):1257-1278.

Chang, CL. 2010. The study of the turnover of MIS professionals: The gap between Taiwanese and US societies. International Journal of Information Management 30(4):301-314.

Clinton-Baker, M. 2013. The relationship between career anchors, organisational commitment and turnover intention. Unpublished Master's dissertation, University of South Africa, Pretoria, South Africa.

Coetzee, M \& Schreuder, AMG. 2008. A multi-cultural investigation of students' career anchors at a South African higher education institution. South African Journal of Labour Relations 32(2):45-65.

Coetzee, M \& Schreuder, D. 2009. Using the careers orientations inventory (COI) for measuring internal career orientations in the South African organisational context. South African Journal of Industrial Psychology 35(1):1-13.

Coetzee, M, Schreuder, AMG \& Tladinyane, R. 2007. Career anchors and its relation to organisational commitment. Southern African Business Review 11(1):65-86.

Coetzee, M, Schreuder, AMG \& Tladinyane, RT. 2014. Employees' work engagement and job commitment: The moderating role of career anchors. South African Journal of Human Resource Management 12(1):1-12.

Cohen, J. 1992. Quantitative methods in psychology: A power primer. Psychological Bulletin 112(1):155-159.

Davidson, MCG, Timo, N \& Wang, Y. 2010. How much does labour turnover cost?: A case study of Australian four- and five-star hotels. International Journal of Contemporary Hospitality Management 22(4):451-466.

Deloitte. 2012. Talent 2020: Talent management trends in a turbulent economy SIOPSA Event 24 February 2012. CSIR, Pretoria: Deloitte Development.

Ding, CG \& Lin, C. 2006. Comparing the effects of determinants of turnover intentions between Taiwanese and U.S. hospital employees. Human Resource Development Quarterly 17(4):403-421.

Döckel, A. 2003. The effect of retention factors on organisational commitment: An investigation of high technology employees. Unpublished Master's dissertation, University of Pretoria, Pretoria.

Dysvik, A \& Kuvaas, B. 2010. Exploring the relative and combined influence of masteryapproach goals and work intrinsic motivation on employee turnover intention. Personnel Review 39(5):622-638.

Ezirim, CB, Nwibere, BM \& Emecheta, BC. 2012. The influence of corporate culture on organisational commitment: The Nigerian experience. International Journal of Business \& Public Administration 9:155-180. 
Feldman, DC \& Bolino, MC. 2000. Career patterns of the self-employed: Career motivations and career outcomes. Journal of Small Business Management 38(3): 53-67.

Gellatly, IR, Meyer, JP \& Luchak, AA. 2006. Combined effects of the three commitment components on focal and discretionary behaviors. Journal of Vocational Behavior 69:331-345.

Hair, JF, Black, WC, Babin, BJ \& Anderson, RE. 2010. Multivariate data analysis. 7th edition. London: Pearson Prentice-Hall.

Hart, C, Stachow, GB, Farrell, AM \& Reed, G. 2007. Employer perceptions of skills gaps in retail: Issues and implications for UK retailers. International Journal of Retail \& Distribution Management 35(4):271-288.

Herrbach, O \& Mignonac, K. 2012. Perceived gender discrimination and women's subjective career success: The moderating role of career anchors. Relations Industrielles 67(1):25-50.

Holtom, BC, Mitchell, TR, Lee, TW \& Eberly, MB. 2008. Turnover and retention research: A glance at the past, a closer review of the present, and a venture into the future. The Academy of Management Annals 2(1):231-274.

Hom, PW, Mitchell, TR, Lee, TW \& Griffeth, RW. 2012. Reviewing employee turnover: Focusing on proximal withdrawal strategies and an expanded criterion. Psychological Bulletin 138(5):831-858.

Hsu, MK, Jiang, JJ, Klein, G \& Tang, Z. 2003. Perceived career incentives and intent to leave. Information and Management 40:361-369.

Jain, V. 2010. Survival skills of business management graduates: A study with reference to retail and banking. Far East Journal of Psychology and Business 1(4):59-77.

Jiang, K, Liu, D, McKay, PF, Lee, TW \& Mitchell, TR. 2012. When and how is job embeddedness predictive of turnover? A meta-analytic investigation. Journal of Applied Psychology 97(5):1077-1096.

Jones, E, Massey Kantak, D, Futrell, CM \& Johnston, MW. 1996. Leader behavior, work-attitudes, and turnover of salespeople: An integrative study. Journal of Personal Selling and Sales Management XVI (2):13-23.

Joo, B \& Park, S. 2010. Career satisfaction, organizational commitment, and turnover intention: The effects of goal orientation, organizational learning culture and development feedback. Leadership and Organization Development Journal 31(6):482-500.

Kniveton, BH. 2004. Managerial career anchors in a changing business environment. Journal of European Industrial Training 28(7):564-573.

Kuo, YK. 2013. Organisational commitment in an intense competition environment. Industrial Management \& Data System 113(1):39-59.

Lazar, BL. 2005. Occupational and organizational commitment and turnover intention of employees. Unpublished doctoral thesis, University of Phoenix, Phoenix, AZ.

Lee, H \& Liu, C. 2007. An examination of factors affecting repatriates' turnover intentions. International Journal of Manpower 28(2):122-134.

Leong, FTL, Rosenberg, SD \& Chong, S. 2014. A psychometric evaluation of Schein's (1985) career orientations inventory. Journal of Career Assessment 22(3):524-538. 
Lumley, EJ, Coetzee, M, Tladinyane, RT \& Ferreira, N. 2011. Exploring the job satisfaction and organisational commitment of employees in the information technology environment. Southern African Business Review 15(1):100-118.

Mallol, CM, Holtom, BC \& Lee, TW. 2007. Job embeddedness in a culturally diverse environment. Journal of Business Psychology 22:35-44.

Manetjie, O. \& Martins, N. 2009. The relationship between organisational culture and organisational commitment. South African Business Review 13(1):87-111.

Martin, A \& Roodt, G. 2008. Perceptions of organisational commitment, job satisfaction and turnover intentions in a post-merger South African tertiary institution. South African Journal of Industrial Psychology 34(1):23-31.

Mathieu, J \& Zajac, D. 1990. A review and meta-analysis of the antecedents, correlates and consequences of organisational commitment. Psychological Bulletin 108(2): 171-194.

McKay, PF, Avery, DR, Tonidandel, S, Morris, MA, Hernandez, M \& Hebl, MR. 2007. Racial differences in employee retention: Are diversity climate perceptions the key? Personnel Psychology 60:35-62.

Meister, JC \& Willyerd, K. 2010. The 2020 workplace: How innovative companies attract, develop, and keep tomorrow's employees today. New York, NY: HarperCollins.

Meyer, JP \& Allen, NJ. 1997. Commitment in the workplace: Theory, research and application. London: Sage.

Meyer, JP, Allen, NJ \& Smith, CA. 1993. Commitment to organizations and occupations: Extension and test of a three-component conceptualization. Journal of Applied Psychology 78(4):538-551.

Meyer, JP, Hecht, TD, Gill, H \& Toplonytsky, L. 2010. Person-organization (culture) fit and employee commitment under conditions of organizational change: A longitudinal study. Journal of Vocational Behavior 76:458-473.

Meyer, JP, Morin, AJS \& Vandenberghe, C. 2015. Dual commitment to organization and supervisor: A person-centered approach. Journal of Vocational Behavior 88: 56-72.

Meyer, JP, Stanley, LJ \& Parfyonova, NM. 2012. Employee commitment in context: The nature and implication of commitment profiles. Journal of Vocational Behavior 80(1):1-16.

Mignonac, K \& Herrbach, O. 2003. Managing individual career aspirations and corporate needs: A study of software engineers in France. Journal of Engineering and Technology Management 20:205-230.

Mitchell, TR, Holtom, BC, Lee, TW, Sablynski, CJ \& Erez, M. 2001. Why people stay: Using job embeddedness to predict voluntary turnover. Academy of Management Journal 44(6):1102-1121.

Mobley, WH, Griffeth, RW, Hand, HH \& Meglino, BM. 1979. Review and conceptual analysis of the employee turnover process. Psychological Bulletin 86(3):493-522.

Mowday, RT, Porter, LW \& Steers, R. 1982. Employee organizational linkages: The psychology of commitment, absenteeism, and turnover. New York, NY: Academic Press. 
Mulaudzi, LR. 2015. The moderating role of graduate skills and attributes in relation to the employability and retention of graduates in a retail organisation. Unpublished Master's dissertation, University of South Africa, Pretoria, South Africa.

Pienaar, J, Sieberhagen, CF \& Mostert, K. 2007. Investigating turnover intentions by role overload, job satisfaction and social support moderation. South African Journal of Industrial Psychology 33(2):62-67.

Quesenberry, JL \& Trauth, EM. 2012. The (dis)placement of women in the IT workplace: An investigation of individual career values and organisational interventions. Information Systems Journal 22:457-473.

Ramakrishna, HV \& Potosky, D. 2003. Conceptualization and exploration of composite career anchors: An analysis of information systems personnel. Human Resource Development Quarterly 14(2):199-214.

Saif, SK, Nawaz, A, Jan, FA \& Khan, MI. 2012. Synthesizing the theories of job satisfaction across the cultural/ attitudinal dementions. International Journal of Contingency Research \& Business 3(9):1382-1396.

Schein, EH. 1971. The individual, the organization, and the career: A conceptual scheme. The Journal of Applied Behavioral Sciences 7:401-426.

Schein, EH. 1978. Career dynamics: Matching individual and organizational needs. Boston, MA: Addison-Wesley.

Schein, E.H. 1990. Career anchors: Discovering your real values. San Diego, CA: Pfeifer.

Schein, EH. 1996. Career anchors revisited: Implications for career development in the $21^{\text {st }}$ century. The Academy of Management Executive 10(4):80-88.

Schein, EH. 2006. Career anchors: Participant workbook. 3rd edition. San Francisco, CA: Pfeiffer.

Schein, EH. 2013. Career anchors revisited: Implications for career development in the 21st century. In: K Inkson \& ML Savickas (eds). Career studies, Volume I: Foundations of career studies. London: Sage, pp 235-244.

Siong, ZMB, Mellor, D, Moore, KA \& Firth, L. 2006. Predicting intention to quit in the call centre industry: Does the retail model fit? Journal of Managerial Psychology 21(3):231-243.

Somers, MJ. 1995. Organizational commitment, turnover and absenteeism: An examination of direct and indirect effects. Journal of Organizational Behavior 16(1):49-58.

Spagnoli, P \& Caetano, A. 2012. Personality and organisational commitment: The mediating role of job satisfaction during socialisation. Career Development International 17(3):255-275.

Statistical Package for the Social Sciences (SPPS). 2010. Statistical Programs for Social Sciences (SPSS): Version 17.0. Chicago: SPSS Inc.

Steele, C \& Francis-Smythe, J. 2010, July. Investigating the role of career anchor congruence. Symposium paper presented at the 27th International Congress for Applied Psychology, Melbourne, Australia.

Steers, RM \& Mowday, RT. 1981. Employee turnover and post-decision justification. In L.L. Cummings \& B.M. Staw (eds). Research in organizational behaviour. Greenwich, CT: JAI Press:235-281. 
Sudha, S. 2012. A study on retention strategies in retail industry with special reference to Big Bazaar. International Journal of Logistics \& Supply Chain Management Perspectives 1(1):22-27.

Tabachnick, BG \& Fidell, LS. 2007. Using multivariate statistics. Boston: Pearson International.

Tian-Foreman, W. 2009. Job satisfaction and turnover in the Chinese retail industry. Chinese Management Studies 3(4):356-378.

Wils, L, Wils, T \& Tremblay, M. 2010. Toward a career anchor structure: An empirical investigation of engineers. Industrial Relations 65(2):236-256.

Yin-Fah, BC, Foon, YS, Chee-Long, L \& Osman, S. 2010. An exploratory study of turnover intentions among private sector employees. International Journal of Business and Management 5(8):57-64.

Zimmerman, RD \& Darnold, TC. 2009. The impact of job performance on employee turnover intentions and the voluntary turnover process: A meta-analysis and path model. Personnel Review 38(2):142-158. 